2017-11

Discussion on 'An enigmatic echinoid spine from south Devon, UK: Devonian or Cretaceous?', Proceedings of the Yorkshire Geological Society , 61, 165167

Hart, MB

http://hdl.handle.net/10026.1/15151

10.1144/pygs2017-396

Proceedings of the Yorkshire Geological Society

All content in PEARL is protected by copyright law. Author manuscripts are made available in accordance with publisher policies. Please cite only the published version using the details provided on the item record or document. In the absence of an open licence (e.g. Creative Commons), permissions for further reuse of content should be sought from the publisher or author. 


\title{
Discussion on 'An enigmatic echinoid spine from south Devon, UK: Devonian or Cretaceous?', Proceedings of the Yorkshire Geological Society, 61, 165-167
}

\author{
M. B. Hart \\ School of Geography, Earth \& Environmental Sciences, Plymouth University, Drake Circus, Plymouth PL4 8AA, UK \\ mhart@plymouth.ac.uk
}

Received 20 May 2017; revised 29 May 2017; accepted 29 May 2017

The echinoid spine described by Donovan \& Fearnhead (2017) is reportedly from close to the famous Wolborough Quarry [SX 852704], which is located just to the SW of Newton Abbot in south Devon. The Middle Devonian limestones of this quarry have been described by Scrutton (1978), Leveridge et al. (2003), Leveridge (2011) and Wilmut et al. (2014). As indicated by the authors, and previous research, cherts are exceedingly rare in these limestones.

The paper explores the possibility that these echinoderm spines are Cretaceous in age. This seems to be the most likely explanation as both cherts and flints of Cretaceous age are known from the surrounding area. There are two immediate possibilities:

(1) cherts of mid-Cretaceous (Albian) age that are locally well-known; or

(2) flints of Turonian-Campanian age that have been described from the nearby Haldon Hills, and are derived from a time when Dartmoor was, almost certainly, inundated by the Cretaceous sea.

\section{Mid-Cretaceous cherts}

Around the Bovey Basin are a series of outcrops of the Upper Greensand Formation, the majority of which contain brown to grey-coloured cherts in which one can often identify the original bedding structures and bioturbation. One of the best localities in which to see these cherts is Zig Zag Quarry [SX 878690], which lies immediately to the SE of Newton Abbot in the Decoy Basin. A working quarry, it is often difficult to access a face within the Upper Greensand Formation in which the cherts can be found. These are the Cullum Sandswith-Cherts Member of the Haldon Sands Formation (Hamblin \& Wood 1976) and are characteristically coarseto fine-grained, glauconitic sands with layers of nodular, brown, fresh chert. Overlying the in-situ Cretaceous rocks are the Aller Gravels that are formed of sands, silts, and containing abraded flints and cherts. These are thought to be of Paleogene age (Edwards 1973; Edwards \& Freshney 1982; Selwood et al. 1984).

The cherts from both deposits are exceptionally fossiliferous, often being crowded with fossils such as bivalves
(Exogyra sp.), serpulids (Rotularia concava) and the large foraminiferid Orbitolina sp. (see Nicholas \& Hart 2004, fig. 2). Orbitolinids have also been recorded at Wolborough (Schroeder et al. 1986), where - in 1974 - a trench was constructed [SX 855700] near the limestone quarry in order to expose the Upper Greensand Formation that had been discovered during the BGS-funded re-mapping of the area by the University of Exeter (Selwood et al. 1984, p. 122, fig. 21).

\section{Upper Cretaceous flints}

Resting on the Upper Greensand Formation across the top of the Haldon Hills are a series of flint gravels of ?Eocene age (JukesBrowne \& Hill 1904; Hancock 1969; Hart 1982). The fauna collected from these flint gravels ranges from the Sternotaxis planus Zone of the Turonian to the Belemnitella mucronata Zone of the mid-Campanian. Similar gravels are also known from a number of locations across SE England, including Orleigh Court in north Devon (Rogers \& Simpson 1937).

\section{Summary}

There are a great many potential sources of fossiliferous cherts and flints in the Newton Abbot area of south Devon. A study of the specimen should indicate if it is typical of either of these chert or flint assemblages as they appear very different, even in hand specimen. It is not possible to speculate which is the case using the image presented in Donovan \& Fearnhead (2017, fig. 1).

\section{Scientific editing by Steven K. Donovan}

\section{References}

Donovan, S.K. \& Fearnhead, F.E. 2017. An enigmatic echinoid spine from south Devon, UK: Devonian or Cretaceous? Proceedings of the Yorkshire Geological Society, 61, 165-167.

Edwards, R.A. 1973. The Aller Gravels: Lower Tertiary braided river deposits in south Devon. Proceedings of the Ussher Society, 2, 608-616.

Edwards, R.A. \& Freshney, E.C. 1982. The Tertiary sedimentary rocks. In: Durrance, E.M. \& Laming, D.J.C. (eds) The Geology of Devon. Exeter University Press, Exeter, 204-237.

Hamblin, R.J.O. \& Wood, C.J. 1976. The Cretaceous (Albian-Cenomanian) stratigraphy of the Haldon Hills, south Devon. Newsletters on Stratigraphy, 4 , 135-149.

Hancock, J.M. 1969. Transgression of the Cretaceous sea in South West England. Proceedings of the Ussher Society, 2, 61-83. 


\section{B. Hart}

Hart, M.B. 1982. The marine rocks of the Mesozoic. In: Durrance, E.M. \& Laming, D.J.C. (eds) The Geology of Devon. Exeter University Press, Exeter, 179-203.

Jukes-Browne, A.J. \& Hill, W. 1904. The Cretaceous Rocks of Britain: The Upper Chalk of England. Memoirs of the Geological Survey of Great Britain, London.

Leveridge, B.E. 2011. The Looe, South Devon and Tavy basins: the Devonian rifted passive margin successions. Proceedings of the Geologists' Association, London, 122, 616-717.

Leveridge, B.E., Scrivener, R.C., Goode, A.J.J. \& Merriman, R.J. 2003. Geology of the Torquay district - a brief explanation of the geological map. Sheet 350 Torquay. Sheet Explanation of the British Geological Survey, ii +34 .

Nicholas, C. \& Hart, M.B. 2004. Mid-Cretaceous orbitolinids, from the Decoy Basin, Newton Abbot (Devon). Geoscience in south-west England, 11, 10-14.
Rogers, I. \& Simpson, B. 1937. The flint gravel deposits of Orleigh Court, Buckland Brewer, north Devon. Geological Magazine, 74, 309-316.

Schroeder, R., Simmons, M.D., Hart, M.B. \& Williams, C.L. 1986. A note on the occurrence of Orbitolina (Orbitolina) sefini Henson, 1948 (Foraminiferida) in the Upper Greensand of S.W. England. Cretaceous Research, 7, 381-387.

Scrutton, C.T. 1978. Eastern south Devon. In: Scrutton, C.T. (ed.) A Field Guide to selected areas of the Devonian of South West England. International Symposium on the Devonian System (P.A.D.S. 78), September 1978. Palaeontological Association, London, 27-49.

Selwood, E.B., Edwards, R.A. et al. 1984. Geology of the Country around Newton Abbot. Memoir of the British Geological Survey, HMSO, London.

Wilmut, J., Proctor, C. \& Jean, D. 2014. Exploring the limestones of south Devon: a guide to walks that discover the limestones and caves of the county. William Pengelly Cave Studies Trust, Buckfastleigh. 